\title{
Training Multiple Intelligences (Visual-spasial and Linguistic Intelligence) of Students Through Guided Inquiry Model Lesson on Reaction Rate Chapter
}

\author{
Muhammad Andi Tanri Prasetyo, Dian Novita* \\ Chemistry Department, Faculty of Mathematic and Science \\ Universitas Negeri Surabaya \\ Surabaya, Indonesia \\ diannovita@unesa.ac.id
}

\begin{abstract}
This study aims to describe the learning outcomes of multiple intelligences (visual-spatial and linguistic intelligence) of students who are raised with inquiry learning model that is guided on the reaction rate material at SMAN 1 Krian Sidoarjo. This type of research is pre-experimental with One group Pre-test-Post-test Design. Data collection methods Multiple intelligence learning outcomes are a test method of visual-spatial intelligence and portfolio methods of linguistic intelligence. The results of research from the data obtained on the average score of learning outcomes of some students' intelligence on visual-spatial and linguistic intelligence. The learning outcomes of some students' intelligence on the average visual-spatial intelligence score of 78 scores were included in the category of due dilemma over the KKM limit of 75 with an average score of 0.73 (high). Learning outcomes on linguistic intelligence average list Score 88 of the use of student practicum reports and included in the excellent category.
\end{abstract}

Keywords- Guided Inquiry, Learning result of multiple intelligences, Reaction Rate

\section{INTRODUCTION}

Education is a one thing very important and near in every human live around the world about century. Indonesia country definite was having modality for answer world needed from education development is pour inside country rule especially in Law Number 20 Year 2003 about National Education System[1]. Explanations related to these competencies are fully contained in the 2013 curriculum that has been refined by the government through various studies and in-depth evaluations to answer the demands of educational development in accordance with the mandate of the National Education System. The 2013 curriculum that applies in Indonesia contains the competency dimensions as explained in the previous paragraphs, which are related to the dimensions of multiple intelligences. Machali (2014) states the dimensions of multiple intelligences in the development of the realm of attitudes can be included in the scope of Interpersonal intelligence, in the realm of knowledge can be included in the scope of logical-mathematical and visualspatial intelligence, while in the realm of skill can be included in the scope of Linguistic intelligence. Machali (2014) added that competency relationships in the 2013 curriculum with multiple intelligences dimensions occur because the relevance of the 2013 curriculum contents with learning principles that develop multiple intelligences or multiple intelligences is one of the principles in paying attention to all students' intellectual abilities and evaluating contextual learning processes [2] . The results of a pre-study questionnaire of $71 \%$ of 100 students revealed in chemistry learning at SMAN 1 Krian Sidoarjo often applied with the lecture method. As many as $61 \%$ of the 100 students stated that rarely even $15 \%$ said they had never received the chemistry learning process with a discussion method. As many as $54 \%$ of the 100 students explained rarely and $6 \%$ even stated that they had never been in chemistry experiments to find a conclusion with the scientific method. One learning model that is expected to be a solution to the fact gap in SMAN 1 Krian Sidoarjo and the 2013 curriculum hope is a guided inquiry learning model which can later facilitate the process of finding conclusions from conducting experiments during the chemistry learning process. Guided inquiry according to Hackling (2005) is at the level of inquiry that the problems and equipment have been presented by the teacher and for the experimental procedure prepared by students who collaborate with the teacher and find the concept or conclusion of the experiment students are guided to find independently. Strengthening the need for guided inquiry learning models can be seen from the results of a prestudy questionnaire which stated $80 \%$ of 100 students like to solve problems by conducting experiments or experiments in chemistry learning plus the results of pre-research questionnaires $53 \%$ of 100 students stated rarely and 5\% stated never in chemistry learning is given the application knowledge in everyday life. Thus, the guided inquiry learning model revealed in Permendikbud No. 22 of 2016 as a learning model suggested for learning natural science subjects in this case chemistry lessons by looking at the facts of the field facts it is very appropriate to be applied in order to return in line with expectations that are in accordance with the mandate of the National Education System. Asni (2015) states that with the application of guided inquiry learning models students become more able to solve problems and make tentative hypotheses that can be answered through the results of experiments conducted by students themselves [3].

Characteristics of the rate of reaction in the realm of knowledge can be explained that involves relationships that 
are expressed in graphical form (Musya'idah, et al, 2016). Students are required to use the potential of visual-spatial intelligence so that relationships in the form of graphs that are explained from the competency of 3.6 material reaction rate can be optimized [4]. Subsequent basic competencies in the realm of skills or skills are 4.7 designing, performing, and concluding and presenting experimental results of factors that influence reaction rates and reaction orders. Characteristics of reaction rate material in the realm of skills emphasize student activity which consists of designing, performing, and concluding according to scientific approaches or methods. Whereas, the material characteristics of the domain reaction rate of skills related to the presentation of experimental results factors that influence the rate of reaction are required with the students' Linguistic intelligence potential in the form of a portfolio assessment that touches the skill dimension in the form of communicative levels of students according to the scientific approach that has been applied. So, it can be concluded that the basic competencies of material rate of reaction in the realm of knowledge and skills or skills are in need of accommodating multiple intelligences, especially visualspatial intelligence and linguistics to optimize the potential of students in line with the demands of competencies contained in the 2013 curriculum as mandated by the National Education System. (Sari, N.K., 2014) states that reaction rate material is very suitable to be associated with learning using an intelligence approach. Students through learning can understand the concept of reaction rates from within themselves. The teacher in this case for the introduction of good learning, especially on the material rate of reaction is to provide phenomena in everyday life [5]. Research by Purnamasari and Admoko (2015) strengthens multiple intelligences in representing competencies in the 2013 curriculum which states that there is a classical increase in students' multiple intelligences, namely $23 \%$ in spatial intelligence, $21 \%$ in linguistic intelligence, $24 \%$ in logicalmathematical intelligence, and $26 \%$ on interpersonal intelligence compared to the other five multiple intelligences which have relatively lower increase in learning [6]. So, overall the background description needs to be researched with the title "Training Multiple Intelligences (visual-spatial intelligence and Linguistics) of Students through the Guided Inquiry Learning Model on Reaction Rate Material in SMAN 1 Krian Sidoarjo".

\section{METHODS}

This type of research is a type of quantitative descriptive research by describing variables systematically, facts, and accurately (Sugiyono, 2011) [7]. This research is a preexperimental study with the design of one group pretest posttest design.

\begin{tabular}{|ccr|}
\hline Pretest & Perlakuan & Posttest \\
$\mathrm{O} 1$ & $\mathrm{X}$ & $\mathrm{O} 2$ \\
\hline
\end{tabular}

(Sugiyono, 2011) [7]

Information :

$\mathrm{O} 1=$ Score of pretest learning outcomes of students who interpret visual-spatial intelligence of students before being given guided inquiry learning models on the material rate of reaction
$\mathrm{X}=$ treatment (treathment) given by applying the guided inquiry learning model in the form of learning outcomes that reflect the multiple intelligences of students

$\mathrm{O} 2=$ Posttest score of learning outcomes that interpret students' visual-spatial intelligence after being given guided inquiry learning models on the material rate of reaction

Learning tools used in this study consist of syllabus, lesson plans, and student worksheets. The instruments used were the pre-test and post-test assessment sheets for visualspatial intelligence and a linguistic intelligence portfolio assessment sheet. Data collection methods for multiple intelligences learning outcomes are test methods on visualspatial intelligence and portfolio methods in linguistic intelligence. The test method in this study is used to describe the level of visual-spatial intelligence of students in the material rate of reaction. Meanwhile, the portfolio method is used to measure the level of students' linguistic intelligence which is indicated by the student practicum report on the reaction rate.

Score data for multiple intelligences on visual-spatial intelligence are obtained from the pre-test and post-test sheets. Analysis of tests carried out related to visual-spatial intelligence using multiple choice questions and descriptions with the subject matter of the sub-material reaction rate factors that influence the rate of reaction. The values obtained by the students showed the level of each intelligence that was associated with visual-spatial which was then analyzed by gain scores to be able to find out the category of increasing student scores according to the calculation below:

$$
\mathrm{N}-\mathrm{Galn}=\frac{S_{20 \mathrm{gt}}-S_{\mathrm{prt}}}{S_{\text {maks }}-S_{\text {pra }}}
$$

explanation:

$S$ post : post-test score

Spre : pre-test score

$S$ maks: ideal maximum score

The acquisition criteria for N-Gain scores can refer to Table 1. Achievement of visual-spatial intelligence of individual students is said to have increased respectively in visual-spatial intelligence which is analyzed with gain scores if they are in the medium or high category.

TABLE I. N-GAIN CRITERIA

\begin{tabular}{|c|c|}
\hline Interval & Category \\
\hline$\langle 6\rangle \geqslant 0.7$ & High \\
\hline $\left.0.7 \geq g_{g}\right\rangle \geq 0.3$ & Medium \\
\hline$(5) \times 0,3$ & Low \\
\hline
\end{tabular}

Analysis of students' visual-spatial completeness is based on the results of an assessment of visual-spatial intelligence tests that individually have an average value of $\geqslant 75$ (KKM) taken from the time of the pre-test and post- 
test. Learning is said to be completed in a classical manner when $75 \%$ of students in the class have an average score from the assessment of visual-spatial test questions according to or exceed the KKM.

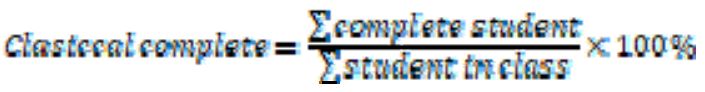

Multiple Intelligence Analysis of linguistic intelligence using a portfolio of experimental reports. The value of the experimental report is a reference to see the level of linguistic intelligence of students based on the values obtained. Assessment is carried out in accordance with the assessment rubric that has been made. Percentage is calculated using the following formula:

\section{Score : $\frac{\sum_{\text {getting score }}}{\text { Eallof scone }} \times 100$}

Then the scores obtained are converted to criteria referring to the table below. Achievement of liguistic intelligence is said to be high if the portfolio value reaches good or very good criteria, which is $\geqslant 61$.

TABLE II. LINGUISTIC SCORE CRITERIA

\begin{tabular}{|r|c|l|}
\hline \multicolumn{1}{|l|}{ No. } & Interval & Criteria \\
\hline 1 & $0-20$ & Poor \\
\hline 2 & $21-40$ & Less \\
\hline 3 & $41-60$ & Adequate \\
\hline 4 & $61-80$ & Good \\
\hline 5 & $81-100$ & Very Good \\
\hline
\end{tabular}

(Adaptation of riduwan, 2011)[9]

\section{RESULT AND DISCUSSION}

\section{A. Results and Discussion}

Learning Outcomes multiple intelligences (visual-spatial intelligence)

TABLE III. LEARNING OUTCOMES OF VISUAL SPATIAL INTELLIGENCE

\begin{tabular}{|c|c|c|c|c|c|}
\hline \multirow{2}{*}{ No. } & \multirow{2}{*}{ Student } & \multicolumn{2}{|c|}{ Visual-spatial } & N- & Criteria \\
\cline { 3 - 4 } & & Pre & Post & Gain & \\
\hline 1 & ANA & 21 & 67 & 0,58 & Medium \\
\hline 2 & ARH & 8 & 75 & 0,73 & High \\
\hline 3 & ARF & 50 & 83 & 0,67 & Medium \\
\hline 4 & ADR & 21 & 75 & 0,68 & Medium \\
\hline 5 & BGW & 21 & 79 & 0,74 & High \\
\hline 6 & BNV & 33 & 63 & 0,44 & Medium \\
\hline 7 & CSM & 29 & 88 & 0,82 & High \\
\hline 8 & ENA & 29 & 92 & 0,88 & High \\
\hline 9 & EAP & 25 & 92 & 0,89 & High \\
\hline 10 & FSR & 17 & 75 & 0,70 & Medium \\
\hline
\end{tabular}

\begin{tabular}{|c|c|c|c|c|c|}
\hline \multirow{2}{*}{ No. } & \multirow{2}{*}{ Student } & \multicolumn{2}{|c|}{ Visual-spatial } & \multirow{2}{*}{ N- } & \multirow{2}{*}{ Criteria } \\
\cline { 3 - 4 } & & Pre & Post & Gain & \\
\hline 11 & KK & 21 & 75 & 0,68 & Medium \\
\hline 12 & KAW & 17 & 71 & 0,65 & Medium \\
\hline 13 & LH & 17 & 75 & 0,70 & Medium \\
\hline 14 & MPM & 25 & 88 & 0,83 & High \\
\hline 15 & MNA & 25 & 75 & 0,67 & Medium \\
\hline 16 & MPR & 17 & 54 & 0,45 & Medium \\
\hline 17 & MYN & 13 & 88 & 0,86 & High \\
\hline 18 & NRS & 17 & 75 & 0,70 & Medium \\
\hline 19 & NKA & 25 & 92 & 0,89 & High \\
\hline 20 & NF & 17 & 71 & 0,65 & Medium \\
\hline 21 & NAM & 29 & 88 & 0,82 & High \\
\hline 22 & RMI & 29 & 88 & 0,82 & High \\
\hline 23 & RABB & 13 & 75 & 0,71 & High \\
\hline 24 & SSR & 21 & 79 & 0,74 & High \\
\hline 25 & UTW & 17 & 83 & 0,80 & High \\
\hline 26 & WMA & 17 & 96 & 0,95 & High \\
\hline 27 & YRP & 8 & 71 & 0,68 & Medium \\
\hline 28 & ZA & 17 & 79 & 0,75 & High \\
\hline 29 & CMP & 4 & 67 & 0,65 & Medium \\
\hline 30 & RAP & 21 & 71 & 0,63 & Medium \\
\hline & Rates & 21 & 78 & 0,73 & High \\
\hline
\end{tabular}

Based on the data contained in Table 3 revealed that the learning outcomes on the aspect of visual-spatial intelligence on average of 30 students is a pre-test score of 21 and a posttest score of 78 . Visual-spatial intelligence from multiple intelligences views is an ability in think through pictures, the ability to visualize, imagine, create and manipulate images (Armstrong, 2013) [10]. Guided inquiry learning in training multiple intelligences, especially on aspects of visual-spatial intelligence can be seen from the activities of students in certain phases. Activities in certain phases in the form of students can see the pictures of the tools and materials used and students make a flow of experiments visually with the guidance of the teacher in phase 3 guided inquiry. This is in accordance with the opinion of Musya'idah (2016) that making visualization can help students to understand the macroscopic multi representation in the characteristics of the reaction rate. Macroscopic representation is an effective picture that can be seen in plain view through experiments [4]. Macroscopic representation in this study is seen from the creation of a visual flow plot that allows students to make an invisible description of the material rate of reaction. Furthermore, students are trained by teachers related to visual-spatial intelligence, namely through a graph of the relationship of variables for example on the factor of $\mathrm{HCl}$ concentration with the reaction time students are asked to interpret the graph in phase 4 guided inquiry. Finally, in phase 5 guided inquiry the teacher trains visual-spatial intelligence with the form of students being asked to make an 
illustration of the variable relationship for example on the factor of $\mathrm{HCl}$ concentration with the reaction rate of $\mathrm{HCl}$. The teacher also added a symbolic explanation related to the molecule that occurred in the condition of the $\mathrm{HCl}$ concentration factor. Symbolic explanation as to the character of the reaction rate is a multi representation consisting of macroscopic, submicroscopic, and symbolic (Musya'idah, 2016) [4]. Symbolic representation in the material rate of reaction is to make a symbol related to the relationship of variables contained in the concept of the material. Examples of symbolic representations in the rate factor of a reaction are linking molecules with the collision theory which can be made by making symbols about the number of molecules according to the collision theory which shows the suitability of the conditions of the molecule in certain factors. Suppose the molecular conditions at high concentrations and at low concentrations are associated with the reaction rate.

Based on the data disclosed by Table 3 that classically there is an increase in n-gain with medium and high categories showing success in training students' visual-spatial intelligence. This success, although there are eight students who have not achieved the KKM score, can still be said that successful students experience an increase in visual-spatial intelligence from the n-gain obtained. This is in accordance with what was stated by Armstrong (2013) that almost all humans have the capacity to develop the intelligence they possess in a higher level of performance with teaching patterns that are in accordance with that intelligence. The guided inquiry model applied is one model that has succeeded in proving that visual-spatial intelligence can be trained with good improvement results.

Learning outcomes multiple intelligences (linguistic intelligence)

Technically, linguistic intelligence is that one student only works on portopolio or experimental report with one title from the reaction rate experiment carried out and collected one week calculated from the experiment that has been done. The following are assessment results data in the realm of skills that reflect linguistic intelligence summarized in the following Table 4:

TABLE IV. LEARNING OUTCOMES OF LINGUISTIC INTELLIGENCE

\begin{tabular}{|c|c|c|c|c|}
\hline No. & Student & Value & Completeness & Criteria \\
\hline 1 & ANA & 90 & Complete & Very Good \\
\hline 2 & ARH & 86 & Complete & Very Good \\
\hline 3 & ARF & 94 & Complete & Very Good \\
\hline 4 & ADR & 90 & Complete & Very Good \\
\hline 5 & BGW & 80 & Complete & Good \\
\hline 6 & BNV & 76 & Complete & Good \\
\hline 7 & CSM & 86 & Complete & Very good \\
\hline 8 & ENA & 82 & Complete & Very good \\
\hline 9 & EAP & 84 & Complete & Very good \\
\hline
\end{tabular}

\begin{tabular}{|r|c|c|c|c|}
\hline No. & Student & Value & Completeness & Criteria \\
\hline 10 & FSR & 92 & Complete & Very good \\
\hline 11 & KK & 74 & Complete & Good \\
\hline 12 & KAW & 96 & Complete & Very Good \\
\hline 13 & LH & 84 & Complete & Very Good \\
\hline 14 & MPM & 86 & Complete & Very Good \\
\hline 15 & MNA & 92 & Complete & Very Good \\
\hline 16 & MPR & 82 & Complete & Very Good \\
\hline 17 & MYN & 86 & Complete & Very Good \\
\hline 18 & NRS & 96 & Complete & Very Good \\
\hline 19 & NKA & 94 & Complete & Very Good \\
\hline 20 & NF & 90 & Complete & Very Good \\
\hline 21 & NAM & 96 & Complete & Very Good \\
\hline 22 & RMI & 90 & Complete & Very Good \\
\hline 23 & RABB & 90 & Complete & Very Good \\
\hline 24 & SSR & 92 & Complete & Very Good \\
\hline 25 & UTW & 88 & Complete & Very Good \\
\hline 26 & WMA & 90 & Complete & Very Good \\
\hline 27 & YRP & 88 & Complete & Very Good \\
\hline 28 & ZA & 94 & Complete & Very Good \\
\hline 29 & CMP & 94 & Complete & Very Good \\
\hline 30 & RAP & 90 & Complete & Very Good \\
\hline Average in & 88 & Complete & Very Good \\
\hline
\end{tabular}

Based on the data in Table 4 it can be revealed that student learning outcomes in linguistic intelligence are 100\% or 30 students of different answers. This is evidenced by a ratio that only includes statistical minimumity, which is a score of 61 . Data Table 4 shows that $90 \%$ or 27 students get very good grades and $10 \%$ or 3 students get good criticism. Linguistic intelligence from Gardner in Davis (2010) is the ability to speak and write to express yourself [11]. The application of linguistic intelligence according to Widodo (2013) in the learning process is to give students the opportunity to tell stories related to subjects, students are given the opportunity to lead discussions, present a subject matter, compile reports, and link an article to the reality that occurs [12]. In accordance with the opinion of these experts in this study students were trained in linguistic intelligence in certain phases in guided inquiry. The first activity that trains linguistic intelligence is that in phase 1 student guided inquiry based on the example phenomenon is asked to identify the important points that emerge and need to be solved. The activity in phase 1 at the meeting of 1 student is 
still given the overall points that must be identified and students only express the reasons for the points included in the important points. Meetings 2 and 3 students begin to make their own important points from the phenomenon given so that students are trained in written and verbal or verbal linguistic intelligence. Furthermore, although in phases 2 to 4 do not directly train linguistic intelligence because the main focus in this phase is other intelligence teachers can still anticipate to train linguistic intelligence. The strategy that the teacher can use when the phase is while checking the grammar used by students when answering the questions in the LKS. Then, linguistic intelligence is practically trained during the phase 5 guided inquiry, namely by explaining the report formats that will be assigned to students at the end of the third meeting. The teacher gradually explains the writing components that must be in the report. Students are gradually trained to write reports according to the format described by the teacher in the final phase of learning.

There are many benefits obtained by knowing the level of multiple intelligences of students as illustrated by the results of learning visual-spatial intelligence and linguistic intelligence. Chatib (2013: 108) revealed that by knowing the level of multiple intelligences of students, the teacher can package his teaching style so that it is easy for students to understand, the teacher can design learning that is fun and in accordance with the conditions of students, so that student learning outcomes are as expected [13]. Whereas, from the application of guided inquiry in training students' multiple intelligences, Purnamasari (2015) said that the role of the teacher as a facilitator, the teacher should be able to create learning conditions that can help students understand the concepts in their own ways [6]. The opinions of these experts have been proven by the application of guided inquiry learning models in training multiple intelligences so that multiple intelligences of students can be successfully trained with guided inquiry learning models.

\section{CONCLUSIONS}

Based on the results of data analysis it can be concluded in general towards multiple intelligences (visual-spatial and linguistic intelligence) students who are trained on the material of reaction rate in SMAN 1 Krian Sidoarjo can be categorized as being successfully trained thoroughly. The results of these categories can be shown by the acquisition of multiple intelligences learning outcomes of students on visual-spatial intelligence obtained an average score of 78 included in the complete category because it exceeds the KKM limit of 75 with an average gain score of 0.73 (high). Learning outcomes in linguistic intelligence obtained an average score of 88 from the writing of the student practicum report and included in the excellent category.

\section{ACKNOWLEDGMENT}

Thank you to Ms. Dian Novita, S.T., M.Pd. as a Thesis Supervisor who always provides direction, guidance and motivation and has spent a lot of time and energy to guide the compiler in completing this journal. Thank you also to Prof. Dr. Suyono, M.Pd. as Dean of the Faculty of Mathematics and Natural Sciences, Surabaya State University. Thanks are also conveyed to all parties who have been involved in the preparation of this journal until it reaches the completion stage.

\section{REFERENCES}

[1] DPR-RI. Salinan Undang-Undang No. 20 Tahun 2003 Sistem Pendidikan Nasional. Jakarta: DPR-RI, 2003.

[2] Machali, I. Dimensi Kecerdasan Majemuk dalam Kurikulum 2013. Insania, 10(1)., 2014

[3] Asni, \& Novita, D. Penerapan Model Pembelajaran Inkuiri Terbimbing untuk Meningkatkan Keterampilan Proses Siswa pada Materi Laju Reaksi. UNESA Journal of Chemical Education, 4(1), 11-17, 2015.

[4] Musya'idah, Effendy, \& Santoso, A. POGIL, Analogi Model FAR, KBI, dan Laju Reaksi. In Prosiding Semnas Pend. IPA Pascasarjana UM. Malang: Universitas Malang, 2016

[5] Sari, N. K., \& Novita, D. Brain Based Learning Approach on Learning Process Reaction Rate Matter in SMAN 1 Kebomas Gresik. Unesa Journal of Chemical Education, 2014, 3(1), 93-98.

[6] P., W. S., \& Admoko, S. "Application of Learning Based on Comprehensive Intelligence Theory to Improve Student Learning Outcomes of SMA Kartika Wijaya Surabaya on Static Fluid Material (Penerapan Pembelajaran Berdasarkan Teori Kecerdasan Majemuk untuk Meningkatkan Hasil Belajar Siswa SMA Kartika Wijaya Surabaya pada Materi Fluida Statik)". Jurnal Inovasi Pendidikan Fisika, 2015, 4(2), 98-101.

[7] Sugiyono. Metode Penelitian Pendidikan. Bandung: Alfabeta, 2011

[8] Hake, R. R. Analyzing Change/Gain Scores (Terjemahan). Jakarta: Gramedia, 1998

[9] Riduwan. Rumus dan Data dalam Aplikasi Statistika. Bandung: Alfabeta, 2011.

[10] Armstrong, T. Kecerdasan Multipel di dalam Kelas. Jakarta: Indeks, 2013.

[11] Gardner, H. 2003. Multiple Intelligences (Terjemahan). Batam: Interaksara.

[12] Widodo, T. pembelajaran Aktif Meningkatkan kecerdasan Ganda Siswa, 2013. Diambil 12 April 2018, dari http;//guru.or.id/pembelajaran-aktif-meningkatkan-kecerdasan-gandasiswa.html

[13] Chatib, M. Sekolahnya Manusia. Bandung: Kaifa, 2013. 